\title{
Profiel van afgestudeerde B.Cur studente van 1997
}

\author{
S Ballack, B.Cur; Departement Verpleegkunde, RAU \\ A Botes, D.Cur; wyle Professor, Departement Verpleegkunde, RAU
}

\section{Opsomming}

Die doel van die studie is om die profiel van die afgestudeerde B.Cur.-studente wat in 1997 hul studies aan die Randse Afrikaanse Universiteit voltooi het, te beskryf.

Daar is gebruik gemaak van die volgende teoretiese vertrekpunte, naamlik Muller se beskrywing van loopbaanbestuur (Muller, 1998: 353-362) en Northeastern University se vyf-stap-model van loopbaandienste (Northeastern University, sa: 1).

Deur al die bepaalde faktore in ag te neem wat ' $n$ rol in loopbaanbestuur speel, kan ' $n$ volledige profiel van die afgestudeerde B.Cur.-student van 1997 saamgestel word. Dit is verder belangrik vir die verpleegonderwysinstelling om kennis te dra van die profiel van afgestudeerdes ten einde die program volgens die behoeftes van die leerder aan te pas.

Met 'n kwantitatiewe opname-ontwerp is data telefonies aan die hand van ' $n$ selfopgestelde vraelys ingesamel. Die gestruktureerde vraelys het inhoudsgeldigheid op grond van die konseptualisering. Data van nege-entwintig van die een-en-dertig studente is ingesamel. Beskrywende statistiek is gebruik in die analise van die data.

Die profiel van die afgestudeerde studente is volgens veertien faktore uit die vraelys beskryf.

\section{Abstract}

The purpose of this study is to describe the profile of the B.Cur. graduates who completed their studies in 1997 at the Rand Arikaans University.

Theoretical points of departures were used, such as Muller's career management description (Muller, 1998: 353-362) and Northeastern University's five-step model career services (Northeastern University, sa:1).

After taking all the factors into consideration that play a role in career management, the researcher will be able to compile a complete profile of the B.Cur. graduates of 1997. It is important to the nursing education institution to know the profile of the graduates, in order to adapt the programme to the needs of the students.

With a quantitative survey design, data was gathered telephonicaly, through a self-composed questionnaire. The structured questionnaire has content validity in terms of conceptualisation. Of the thirty-one students, data was gathered on twenty-nine of them. Descriptive statistics were used to analise the data.

The profile of the graduates is described according to fourteen factors from the questionnaire.

\section{Inleiding en probeemstelling}

Die doel van die studie is om die profiel van die afgestudeerde B.Cur.-studente wat hul studies in 1997 voltooi het, te beskryf.

Volgens Moore (in Walters, 1997:1) is alle persone bestuurders wat hul eie belange rig en hul eie lewens beheer. Dit is dus duidelik dat die verpleegkundige, die bestuurder van haar eie loopbaan is. Daar word na hierdie proses van bestuur as loopbaanbestuur verwys. Muller (1998:354) verwys daarna as die proses waarvolgens die verpleegpraktisyn loopbaandoelwitte stel en 'n weg identifiseer waarvolgens sy hierdie doelwitte kan realiseer.

Alle volwassenes gaan deur vyf sikliese stappe tydens die keuse van 'n nuwe loopbaan of met die verwisseling van loopbane. (Northeastern University, sa: 1). Hierbenewens verwys Muller (1998:357) ook na ' $n$ aantal beginsels binne loopbaanbestuur, naamlik selfkennis, vryheid van keuse, drome en doelwitte, planne van aksie, evaluasie en herbeplanning. Dit is duidelik dat die verpleegkundige deur sekere stappe gaan om haar loopbaan te bestuur of dat daar bepaalde faktore is wat haar keuse van loopbaan beïnvloed.

Dit sluit onder andere selfkennis en familie-aangeleenthede in. Muller (1998:357) identifiseer selfkennis as die "proses waartydens die verpleegpraktisyn haar begeertes en verwagtinge bepaal sowel as om haar unieke karaktertrekke te identifiseer". Verder noem Muller (1998:360) ook dat familie 'n rol sal speel tydens loopbaankeuse weens die feit dat vrouens $97 \%$ van die arbeidskrag binne verpleging uitmaak.

' $n$ Verdere faktor is loopbaan- en studiegeleenthede. Die opsies binne verpleegkunde is eindeloos (Kimmel, 1998: 
1). Dit is dus nodig dat die verpleegkundige kennis dra van, en navorsing doen oor die verskeidenheid van loopbane wat beskikbaar is. Die veranderinge in die werksomgewing vereis dat die verpleegkundige nuwe vaardighede moet aanleer (Northeastern University, sa: 1 ).

Kimmel (1998:2) noem egter dat dit belangrik is dat die individu persoonlike en professionele doelwitte stel om sodoende as algemene riglyne te dien. Hierdie doelwitte stel die verpleegkundige in staat om alle aksies te rig.

Met die oog op die keuse van ' $n$ nuwe of ander loopbaan noem Northeastern University (sa: 1 ) egter dat dit belangrik is dat die individu oor die nodige onderhoudsvaardighede beskik en dat die individu haar/sy skryfvaardighede hersien of ontwikkel. Northeastern University (sa: 1) vermeld egter ook dat dit belangrik is dat die organisering en kulture van die organisasie verstaan word, dat die individu ' $n$ mentor vind en dat strategieë ontwikkel word wat waarde aan "n organisasie gee.

Dit is belangrik dat effektiewe loopbaanbestuur plaasvind, want volgens Reitman (2001:1) is dit die een sleutel wat tot verwesenliking en bevrediging lei.

Deur al die bepaalde faktore in ag te neem wat ' $n$ rol in loopbaanbestuur speel, sal die navorser in staat wees om ' $n$ volledige profiel van die afgestudeerde B.Cur.-studente van 1997 saam te stel. Dit is verder belangrik vir die verpleegonderwysinstelling om kennis te dra van die profiel van die afgestudeerde ten einde die program volgens die behoeftes van die leerder aan te pas. Weens die feit dat daar tans geen inligting beskikbaar is oor die afgestudeerde B.Cur student nie, word die vraag gevra:

Wat is die profiel van die afgestudeerde B.Cur.-studente wat hul studies aan ' $n$ bepaalde hoëronderwysinstansie in die jaar 1997 voltooi het?

\section{Doelstelling van die navorsing}

Die doel van die studie is: Om die profiel van die afgestudeerde B.Cur.-student wat haar studie in die jaar 1997 aan ' $n$ bepaalde hoëronderwysinstelling voltooi het, te beskryf.

\section{Definisie van sentrale konsepte en teoretiese begronding}

Tydens die konseptualisering is daar op die volgende aspekte gefokus:

- Uitklaring van sentrale konsepte

- Loopbaanbestuur as teoretiese konsep waarop die vraelys gegrond is.

\section{Verduideliking van sentrale konsepte}

'n "Afgestudeerde student" verwys na alle studente wat hul studies aan dié hoëronderwys instelling in die jaar 1997 voltooi het. Dus beteken dit dat hul aan al die leeruitkomste en assesseringskriteria van die graad Baccalureus Curationis voldoen om as "afgestudeerde" geklassifiseer te word. Die doel van die program word soos volg weergegee: "Die leerder demonstreer die vermoëns om as onafhanklike, beginner- en omvattende verpleegkundige (algemeen, psigiatrie, gemeenskaps), en vroedvrou te praktiseer in die beraming, diagnosering, beplanning, implementering en evaluering van gesondheidsorg aan die individu, gesin, groep en gemeenskap as lid van die gesondheidspan, binne die eties-wetlike raamwerk van verpleging in Suid-Afrika"' (RAU, 2001: 4).

Binne hierdie studie word daar gepoog om die uitsonderlike eienskappe van die afgestudeerde B.Cur student uit te beeld. Om ' $n$ profiel te kan weergee, is dit dus noodsaaklik om ' $n$ begrip te hê van die uitsonderlike eienskappe wat ' $n$ rol in die loopbaanbestuur van die afgestudeerde B.Cur.-student speel. In hierdie studie was studente almal vroulik.

'n Profiel verwys na ' $n$ versameling van data in ' $n$ geskrewe of grafiese voorstelling wat ' $n$ uitsonderlike eienskap, naamlik loopbaanbestuur uitbeeld (Webster, 2001: 1).

\section{Loopbaanbestuur as teoretiese vertrekpunt}

Daar is gebruik gemaak van die volgende teoretiese vertrekpunte, naamlik Muller se beskrywing van loopbaanbestuur (Muller, 1998: 353-362) en Northeastern University se vyf-stap-model van loopbaandienste (Northeastern University, sa: 1). Hierdie teoretiese vertrekpunte word gebruik omrede die student verpleegkundige as volwassene in ' $n$ proses van loopbaanontwikkeling aanspreek.

Volgens Northeastern University (sa: 1) gaan alle volwassenes deur 'n vyf-stap-siklus tydens die keuse van 'n loopbaan of wanneer hul van loopbaan verander. Met betrekking hiermee, het Northeastern University 'n vyf-stapmodel vir loopbaandienste geïdentifiseer, naamlik selfberaming, loopbaanverkenning, besluitneming, beroepsoektog en loopbaanbestuur.

Vir die doel van hierdie studie is Northeastern University (sa:1) se model vir loopbaandienste, geherorganiseer in kombinasie met Muller (1998:353-362) se raamwerk vir loopbaanbestuur. Die stappe van loopbaanbestuur vir doeleindes van die studie kan soos volg bekryf word, naamlik:

- $\quad$ Stap 1 - selfkennis en familie

- Stap 2 - loopbaan- en studiegeleenthede

- Stap 3 - besluitneming en doelstellings

- Stap 4 - werksoektog

- Stap 5-lewenslange leer. 
$\mathrm{Na}$ aanleiding van bogenoemde word die volgende hoofpunte geïdentifiseer wat moontlik " $n$ invloed kan hê op die profiel van die afgestudeerde B.Cur.-student wat sy/ haar studie in die jaar 1997 voltooi het. Die hoofpunte is in die vraelys vervat om die profiel van die afgestudeerde te beskryf.

- Gesinsverpligtinge wat dui op die huwelikstatus van die individu, haar aantal kinders en die ouderdom van die kinders.

- Selfkennis waaoor die individu beskik vir genoegsame kennis met betrekking tot haar eie belange en vaardighede, sowel as persoonlikheidsprofiel, om sodoende ' $n$ loopbaan of werk te kies waarin sy/hy gelukkig kan wees en waarbinne sy professioneel en persoonlik kan ontwikkel.

- Loopbaangeleenthede en loopbaanstatus fokus op die volgende, naamlik of die individu steeds binne verpleging en indien wel, in watter area van verpleging-werk sy tans? Werk die individu op nasionale of internasionale vlak? Gryp sy leierskapsaangeleenthede binne haar loopbaan aan ter wille van professionele ontwikkeling? Voel die individu dat sy die regte loopbaankeuse gemaak het?

- Besluitneming en doelstelling fokus op die individu se bepaalde doelstellings wat haar handelinge en besluitneming rig.

- Werksoektog dui op die aantal werk wat die individu gehad het en of die individu tans werk.

- Lewenslange leer dui op die individu se huidige kwalifikasies deur nagraadse kursusse om sodoende op hoogte te bly met die nuutste wetenskaplike verpleging binne haar veld.

\section{Navorsingsontwerp en - metodes}

Die ontwerp wat tydens die studie gebruik is kan beskryf word as ' $n$ kwantitatiewe, nie-eksperimentele ontwerp (Brink, 1996: 108).

Die nie-eksperimentele ontwerp wat gevolg is, kan as ' $n$ beskrywende opname geklassifiseer word. Weens die feit dat die navorser bloot gesoek het vir akkurate inligting oor die karakteristieke van die bepaalde deelnemers, is hierdie benadering gekies (Brink, 1996: 109).

\section{Populasie en steekproef}

Die teikenpopulasie word beskryf as alle afgestudeerde B.Cur studente wat hul studie aan ' $n$ bepaalde hoëronderwysinstelling het in die jaar 1997 voltooi. Die teikenpopulasie sluit die totaal van 32 vroulike deelnemers/ studente in.

Die bereikbare populasie kan geïdentifiseer word as die deelnemers met wie die navorser telefonies in verbinding getree het of wat gewillig was om aan die studie deel te neem en sluit 29 deelnemers/studente in.
Daar is gebruik gemaak van 'n nie-waarskynlikheidsteekproef, wat beteken dat die deelnemers van die populasie, nie-ewekansig gekies is. Die metode van steekproefneming is ' $n$ gerieflikheidsteekproef, wat behels dat die deelnemers van die studie gekies is op grond van beskikbaarheid van die lede. Die steekproef het dus bestaan uit die 29 lede waarmee daar telefonies in verbinding getree is (Brink, 1996: 140).

Tydens die steekproefneming is daar ook gebruik gemaak van die spesiale tegniek, naamlik sneeubalsteekproeftrekking wat behels dat deelnemers gekies word op grond van bystand in die opsporing en verkryging van ander lede. Dus in die geval van die studie is daar gebruik gemaak van sneeubalsteekproeftrekking om in aanraking te kom met ander afgestudeerde studente waarvan die kontaknommers onbekend is, deur die studente waarvan die kontaknommers wel bekend is (Brink, 1996: 141).

\section{Data-insameling}

Die data is ingesamel by wyse van 'n telefoniese onderhoud aan die hand van 'n gestruktureerde vraelys (Brink, 1996: 148).

Vir die doel van die studie is daar gebruik gemaak van 'n selfopgestelde vraelys (Brink, 1996: 153). Die vraelys is geformuleer vanuit die konseptualisering en beskik dus oor inhoudsgeldigheid. Die volgende aspekte is in die vraelys ingesluit.

$\begin{array}{ll}\text { - } & \text { Huwelikstatus } \\ \text { - } & \text { Aantal kinders } \\ \text { - } & \text { Ouderdom van kinders } \\ \text { - } & \text { Aantal werke } \\ \text { - } & \text { Loopbaanstatus } \\ \text { - } & \text { Huidige werk en posbenaming } \\ \text { - } & \text { Werksbevrediging } \\ \text { - } & \text { Oorsese verpleegondervinding } \\ \text { - } & \text { Nagraadse studie } \\ \text { - } & \text { Toekomsvisie } \\ \text { - } & \text { Loopbaankeuse }\end{array}$

Die vraelys bevat 14 vrae wat ' $n$ tydperk van \pm 10 - 15 minute vat om te beantwoord. Die vraelys is saamgestel uit beide geslote en oop vrae, waarvan die antwoorde op ' $n$ antwoordblad opgeteken is (Brink, 1996: 154-157).

\section{Data-analise}

Ter analisering van data is daar gebruik gemaak van beskrywende statistiek (frekwensies, eenvoudige beskrywende statistiek en persentasies) (Brink, 1996: 180 \& 183).

\section{Geldigheid en betroubaarheid}

Metingsgeldigheid verwys volgens Brink (1996:106) na die mate waartoe ' $n$ instrument akkurate metings gee van dit 
wat dit veronderstel is om te meet, binne die gegewe konteks waarin dit toegepas word, soos reeds bespreek. Die data-insamelingsinstrument het inhoudsgeldigeheid op grond van die konseptualisering.

Interne geldigheid is binne die studie verkry deur gebruik te maak van triangulering van bronne. Met ander woorde, daar is gebruik gemaak van 'n verskeidenheid bronne binne die literatuurstudie ten einde meervoudige perspektiewe van die bepaalde verskynsel te verkry.

\section{Figuur 1 Aantal werke}

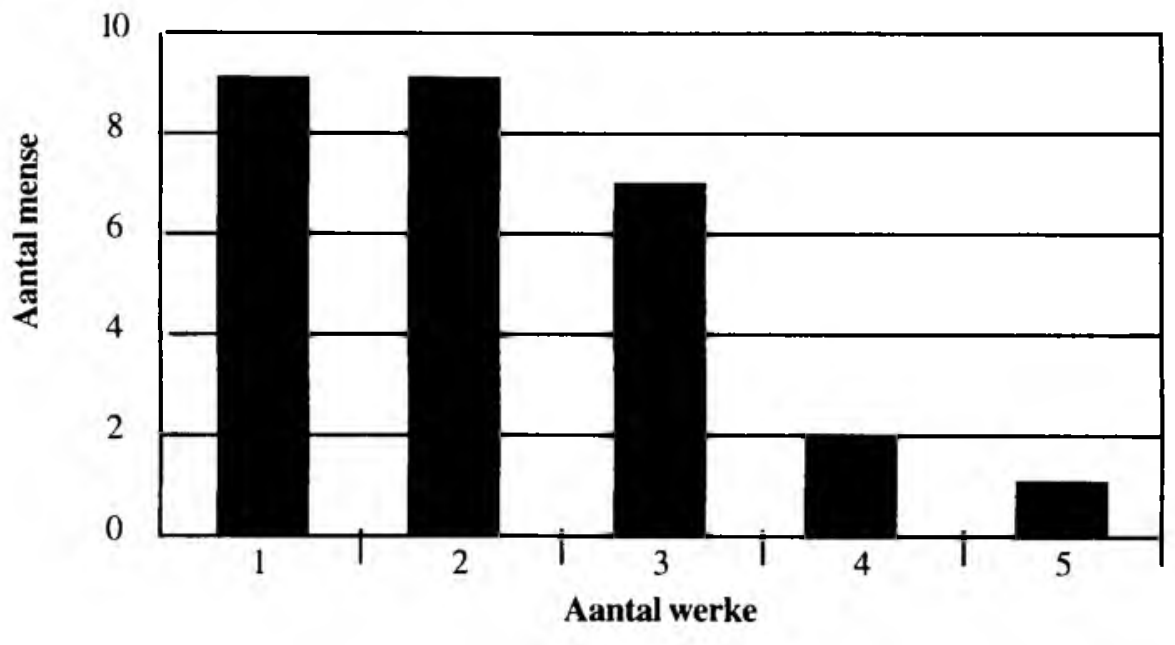

\section{Etiese oorwegings}

Om die regte van die deelnemers te beskerm, is die etiese standaarde van die Universiteit gebruik (RAU, 2001).

\section{Bevindings en gevolgtrekkings van die navorsing}

Elke vraag binne die vraelys se bevindings word afsonderlik bespreek en frekwensies en persentasies word weergegee.

Familieverpligtinge speel " $n$ belangrike rol omdat vrouens die meerderheid van menslike hulpbronne in verpleging uitmaak. Navorsing het reeds gewys dat "huwelik" een van die familieverpligtinge is wat " $\mathrm{n}$ rol in die individu se loopbaanbestuur speel (Watkins et al., 1998: 1).

Uit figuur 1 is dit duidelik dat sewentien uit die nege-entwintig (58.60\%) afgestudeerde studente getroud is en twaalf uit die nege-en-twintig (41.40\%) nie. Daar kan dus afgelei word dat die meerderheid van die studente wel getroud is. Van die individue wat getroud is, is daar slegs twee wat nie ' $n$ bepaalde beroep beklee nie.

Amerikaanse navorsing, soos reeds gemeld, het ook gewys dat die aantal kinders wat ' $n$ individu het ook ' $n$ invloed het op die balans tussen familie en loopbaan (Watkins $e t$ al., 1998: 1). Bogenoemde word hieronder in figuur 3.2 bespreek.

Vyf uit die nege-en-twintig (17.20\%) afgestudeerde B.Cur.studente het wel kinders, terwyl vier-en-twintig uit die negeen-twintig $(82.80 \%)$ nie kinders het nie (Watkins et al., 1998:1).

Navorsing wys egter nie net dat die aantal kinders van 'n individu (Watkins et al., 1998: 1) 'n rol speel in die loopbaan nie, maar ook die ouderdom van die kinders. Volgens Miller het Harmon (1967) die feit dat sommige moeders "terugkeer na die arbeidsmag, wanneer hul kinders ouer is", geïdentifiseer as een van die vrou se loopbaanpatrone (Miller, 1986: 1).

Van die vyf afgestudeerde studente wat wel kinders het, wissel die ouderdom van een kind onder ses maande, geen kinders onder die ouderdom van een jaar nie en drie kinders tussen die ouderdom van een tot vyf jaar. Die netto verskil van een, verwys na een van die afgestudeerde studente met wie daar nie direk in verbinding getree is nie, maar deur haar familie, wat onseker was oor die ouderdom van haar kinders (Watkins et al., 1998: 1).

Hierbenewens is dit dus duidelik dat die minderheid van die afgestudeerde B.Cur.-studente van 1997 wel kinders het.

$\mathrm{Na}$ die identifisering van die biografiese data van die afgestudeerde B.Cur.-studente van 1997 is daar gekyk na hul werksgeskiedenis, om sodoende ' $n$ volledige profiel saam te stel.

Uit die 29 lede van die 32 met wie daar telefonies in verbinding getree is, werk $27(91 \%)$ en $2(6.99 \%)$ nie. Van die twee afgestudeerde studente wat nie werk nie, beklee een die rol van huisvrou en die ander die rol van student binne die mediese veld van geneeskunde. Dit is dus duidelik dat die meerderheid van die afgestudeerde studente steeds werk (Muller, 1998: 360-361).

Volgens Walters het Frähm en Rinehart (1991:39-40;77) genoem dat selfkennis ' $n$ belangrike rol speel in die voorkeur van "n spesifieke werk. In dié geval sal die aantal werke wat die individu alreeds gehad het ' $n$ aanduiding wees van haar selfkennis (Walters, 1997:51).

Aan die ander kant het Muller (1998:354) ook genoem dat loopbaanbestuur die proses is waartydens ' $n$ verpleegpraktisyn sekere loopbaandoelwitte stel en 'n weg identifiseer waarlangs sy of hy die doelwitte kan realiseer. As bogenoemde in ag geneem word, kan die aantal werke 
Tabel 1: Werksgebied \& posbenaming

\begin{tabular}{|c|c|}
\hline WERKSAREA & AANTAL \\
\hline GEMEENSKAPSVERPLEGING & 5 \\
\hline Skoolgesondheid & 0 \\
\hline Beroepsgesondheid & 0 \\
\hline Primêre gesondheidsorg & 5 \\
\hline PSIGIATRIESE VERPLEGING & $\mathbf{0}$ \\
\hline Rehabilitasie & 0 \\
\hline Gemeenskapspsigiatrie & 0 \\
\hline Geestesgestremdheid & 0 \\
\hline VERLOSKUNDIGE VERPLEGING & 4 \\
\hline ALGEMENE VERPLEGING & 7 \\
\hline Trauma & 1 \\
\hline Intensiewesorgverpleging & 2 \\
\hline Neonatale intensiewe sorg verpleging & 1 \\
\hline Operatiewe verpleging (Teater) & 2 \\
\hline Mediese Chirurgiese verpleging & 0 \\
\hline Ortopedies & 1 \\
\hline PATOLOGIE & 2 \\
\hline BESTUUR & 7 \\
\hline Skofleier & 1 \\
\hline Bevelsuster & 3 \\
\hline Bestuurder & 3 \\
\hline ONDERRIG & 1 \\
\hline Mentor & 1 \\
\hline PRIVAAT PRAKTYK & 3 \\
\hline Babamassering & 1 \\
\hline Verloskundekliniek & 1 \\
\hline Gemeenskapsgesondheidskliniek & 1 \\
\hline ANDER & 9 \\
\hline Mediese verteenwoordiger & 5 \\
\hline Gevallebestuurder & 1 \\
\hline Professionele Gesondheidsorgadviseur & 1 \\
\hline Krisiskonsultant & 1 \\
\hline Finansiële kontroleerder & 1 \\
\hline
\end{tabular}

van "n individu moontlik na die "weg" wys waarlangs die afgestudeerde B.Cur.-studente van 1997 hul doelwitte realiseer.

Al die afgestudeerde B.Cur.-studente, wat in 1997 afgestudeer het, reeds ' $n$ pos van een of ander aard beklee.
Nege van die studente het slegs een pos beklee vandat hul afgestudeer het en negentien, meer as een pos. Van die negentien is daar nege wat reeds twee poste beklee het, sewe wat drie poste beklee het, twee wat vier poste beklee het en een wat vyf poste beklee het. Hieruit kan dus afgelei word dat die meerderheid van die afgestudeerde studente 
reeds van beroep verander het (Muller, 1998: 357).

Die netto verskil van een verwys na ' $n$ afgestudeerde student met wie daar nie direk in kontak getree is nie maar via ' $n$ vriendin, wat onseker was oor die aantal beroepe wat die individu reeds beklee het.

Volgens Cardilo (2000:1) is loopbaanbestuur ' $n$ voortdurende proses wat ' $n$ invloed het op die bevordering van die individu se huidige en toekomstige loopbaan

Die meerderheid van die afgestudeerde B.Cur.-studente verkeer steeds binne verpleging. Negentien $(65.50 \%)$ van die nege-en-twintig studente praktiseer steeds binne verpleging, terwyl tien $(34.5 \%)$ van die afgestudeerde studente ander loopbane volg.

Soos reeds genoem kan die verpleegkundige beide op nasionale en internasionele vlak werk (Denosa, 2001). Die meerderheid van die afgestudeerde studente van 1997 werk op nasionale vlak. Vyf-en-twintig uit die nege-en-twintig (86.20\%) afgestudeerde studente van 1997 werk tans nasionaal terwyl twee uit die nege-en-twintig (6.90\%) internasionaal werk. Die balans van 6.90\%, verwys na een student wat tans oorsee bly, maar wat nie binne verpleging praktiseer nie en ' $n$ ander student wat tans op nasionale vlak besig is met studie in die mediese veld en nie binne verpleging werk nie (Denosa, 2001).

Op nasionale vlak kan die verpleegkundige egter ook in die openbare of privaat sektor werk (Muller, 1998: 354). Van die individue wat werksaam is binne die nasionale sektor is die verspreiding soos volg: openbare sektor een uit vyf-entwintig (4\%) en privaat sektor vier-en-twintig uit vyf-entwintig (96\%). Dit is dus duidelik dat die meerderheid van die studente binne die privaat sektor werksaam is. Die $4 \%$ verwys na ' $n$ enkele individu wat tans werksaam is binne ' $n$ bepaalde weermagbasis, waar sy die rang van luitenant beklee en as bestuurderes van die siekeboeg optree (Muller, 1998: 354).

Binne hierdie twee sektore, openbare en privaat sektore, identifiseer Muller (1998:354) egter ook vier hoofdissiplines, naamlik algemene, psigiatriese, gemeenskap en verloskundige verpleging, soos reeds bespreek.

Verspreiding van die verpleegkundiges (respondente) is volgens die vier hoofdissiplines, naamlik psigiatriese verpleging, algemene verpleging, gemeenskapsverpleging en verloskundige verpleging, sowel as patalogie. Twee individue is nie binne " $n$ bepaalde werksarea betrokke nie. Die een het die titel van student en die ander dié van huisvrou.

Geen $(0 \%)$ individue praktiseer binne psigiatriese verpleegkunde nie, sewe $(24.1 \%)$ binne algemene verpleging, vyf $(17,2 \%)$ binne gemeenskapsverpleging, vier $(13,8 \%)$ binne verloskundige verpleging, terwyl nege (31\%) van die individue ander beroepe beklee met " $n$ balans van twee (6.9\%) individue wat nie werk nie (Muller, 1998: 354). $\mathrm{Om}$ ' $\mathrm{n}$ volledige profiel saam te stel is dit egter nodig dat die werke wat deur die afgestudeerde B.Cur.-studente van 1997 binne elke hoofdissipline beklee word, in meer detail bespreek word. Hierbenewens word elke individu se posbenaming ook bespreek en kan sodoende vir die navorser " $n$ aanduiding gee van watter individue bestuursposisies of onderrigposisies beklee (Webster, 2001: 1).

Tabel 1 gee ' $n$ beskrywing van die verskeidenheid werke wat onder die hoofdissiplines geklassifiseer is, sowel as bestuurs- en onderrigposisies wat deur die individue binne die bereikbare populasie beklee word.

Die rede hoekom die netto totaal van 29 oorskry is omdat ' $\mathrm{n}$ aantal van die afgestudeerde studente van 1997 meer as een beroep beklee of ' $n$ beroep beklee, wat onder meer as een van die hoofareas geklassifiseer kan word, bv. ' $n$ individu kan ' $n$ werk binne algemene verpleging beklee maar kan ook ' $n$ bestuursposisie hê, waar sy in diè geval beide onder algemene verpleging en bestuur geklassifiseer sal word. So ook dieselfde met die posbenaming.

Uit tabel 1 is dit dus duidelik dat vyf van die nege-en-twintig afgestudeerde B.Cur.-studente van 1997 binne gemeenskapsverpleging in gemeenskapsgesondheidsklinieke werk. Binne psigiatriese verpleging is daar egter geen studente nie. (Wilson \& Kniesel, 1996: 8).

In verloskundige verpleging is daar 'n totaal van vier afgestudeerde B.Cur.-studente van 1997 (Nolte, 1998: 3).

Sewe afgestudeerde B.Cur.-studente van 1997 praktiseer binne algemene verpleging, maar die verspreiding is egter wyd - een binne trauma, twee binne intensiewesorgverpleging (ICU), een binne neonatale intensiewesorgverpleging (NICU), twee individue binne operasiesaalverpleging (Teater), geen binne mediese/ chirurgiese verpleging nie en een binne ortopedies (Wilson \& Kniesl, 1996: 41).

Twee uit die nege-en-twintig afgestudeerde B.Cur--studente van 1997 werk binne patologie (Muller, 1998: 355).

Van die nege-en-twintig afgestudeerde studente van 1997 is daar sewe wat bestuursposisies beklee, een as skofleier binne algemene verpleging, soos reeds genoem, drie as bevelsusters binne ' $n$ privaat gemeenskapsgesondheidskliniek, ortopedie en binne ' $n$ openbare gemeenskapsgesondheidskliniek en drie as bestuurders binne hulle eie privaat klinieke (Mulier, 1998: 131).

Een van die individue beklee die beroep van mentor binne intensiewesorgverpleging, geklassifiseer onder die veld van onderrig (Muller, 1998: 355).

Drie van die totale afgestudeerde B.Cur.-studente van 1997 besit hul eie privaat praktyk. Hierdie privaat praktyke dek onder andere: babamassering, 'n verloskundige kliniek en 'n gemeenskapsgesondheidskliniek.

Ander beroepe word deur nege van die nege-en-twintig individue gevolg. Hierdie werke en posbenamings is soos 
volg - vyf as mediese verteenwoordigers, een as gevallebestuur, een as professionele gesondheidssorgadviseur, een as krisiskonsultant en een as finansiële kontroleerder.

Om dus op te som, dit is duidelik dat veertien van die afgestudeerde B.Cur.-studente van 1997 oor die posbenaming van geregistreerde verpleegkundige beskik, vier die van vroedvrou, een die van skofleier, drie die van bevelsuster, drie die van bestuurder, een die van mentor en nege die van "ander", soos hierbo genoem.

\section{Figuur 2: Studiemoontlikhede}

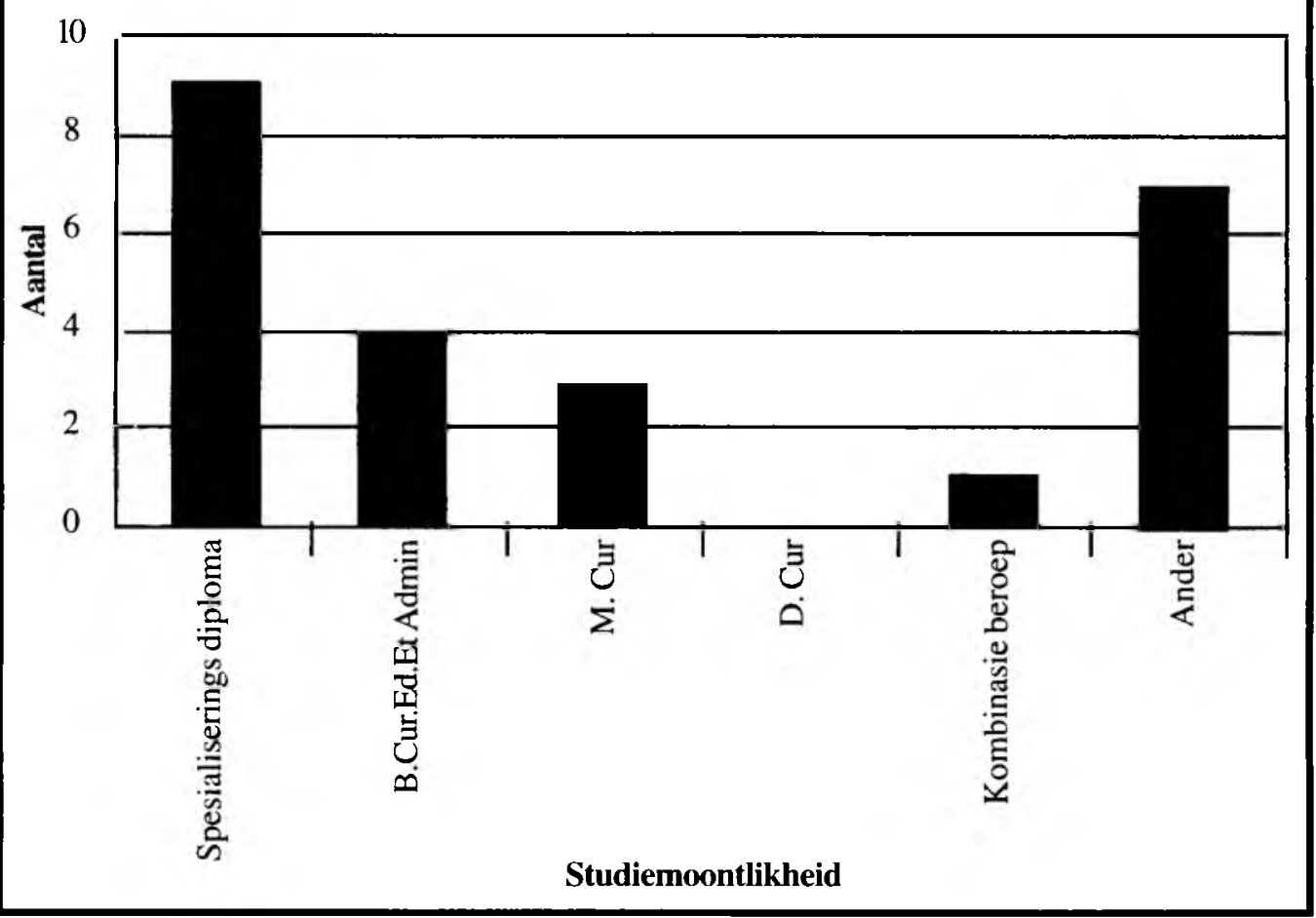

Dit is belangrik om te bepaal tot watter mate die individue gelukkig of ongelukkig is in die pos wat hul tansbeklee, dus hul werksbevrediging. Uit die nege-en-twintig individue is daar een-en-twintig (72.4\%) wat genoem het dat hul wel gelukkig is en vier (13.8\%) dat hul ongelukkig is. Die balans van vier (13.8\%) individue, verwys na drie individue met wie daar nie direk kontak gemaak is nie, maar waarvan data vanaf ' $n$ naasbestaande of vriendin verkry is en persoonlike data, soos bogenoemde dus nie verkry kon word nie. Die ander een individu is tans " $n$ student en beklee dus nie " $n$ bepaalde pos nie. Van die individue wat nie gelukkig binne hulle beroep is nie, werk drie binne verpleging (Muller, 1998: 357).

'n Weergawe van die aantal afgestudeerde studente van 1997 wat verpleegondervinding op internasionale vlak opgedoen het, is gemaak. Van die nege-en-twintig individue binne die bereikbare populasie het twee $(6.90 \%)$ individue oorsese verpleegondervinding terwyl sewe-en-twintig $(91 \%)$ geen verpleegondervinding op internasionale vlak het nie (Denosa, 2001).

Die twee individue wat wel oorsee werk, sluit een in wat beide binne trauma werk sowel as haar studies oorsee bevorder, terwyl die ander individu tans binne verloskundige verpleging in Soedi Arabië werk (Denosa, 2001).

Ingesluit by die $91 \%$ wat geen oorsese verpleegondervinding het nie, is daar wel individue wat internasionaal verkeer het maar nie binne die verpleegprofessie nie. Hul beskik dus nie oor oorsese verpleegondervinding nie. Dit sluit in drie individue van die afgestudeerde B.Cur.-studente van 1997, een wat tans permanent in Frankryk woon en twee wat au pair-werk gedoen het.
Daar is ' $n$ duidelike aanduiding van die aantal afgestudeerde B.Cur.-studente van 1997 wat reeds hul studie bevorder het. Vier $(13.3 \%)$ uit die nege-en-twintig afgestudeerde studente het reeds nagraadse studie onderneem, wat beteken dat hul begin studeer het, maar nog nie hul studie voltooi het nie. Vyftien $(51.7 \%)$ uit die nege-en-twintig afgestudeerde B.Cur.-studente van 1997 het reeds nagraadse studie voltooi terwyl tien $(35 \%)$ individue nog geen studie onderneem het of voltooi, het vandat hul in 1997 afgestudeer het nie. Hierbenewens word die algemene rigting van die afgestudeerde studente in figuur 2 bespreek (Muller, 1998: 357).

Soos reeds bespreek, is daar negentien uit die nege-entwintig afgestudeerde B.Cur.-studente wat of nagraadse studie onderneem het of voltooi het vandat hul in 1997 afgestudeer het. Die totaal binne bogenoemde grafiek oorskry egter negentien omdat van die afgestudeerde studente na-graadse studie in meer as een studieveld onderneem het. Figuur 2 gee die uiteensetting van die moontlike areas van studie (Muller, 1998: 357).

Nege uit die negentien individue het ' $\mathrm{n}$ bepaalde spesialiseringsdiploma onderneem of voltooi (RAU, Fakulteit Opvoedkunde en Verpleegkunde, 2001: 9-13).

Die aard van die spesialiseringsdiploma en die aantal individue kan soos volg uiteengesit word:

- Primêre gesondheidsorg, diagnose en behandeling -1 individu

- $\quad$ Primêre gesondheidsorg, kliniese evaluering - 1 individu

- Primêre gesondheidsorg, "Reproductive Health" 1 individu 


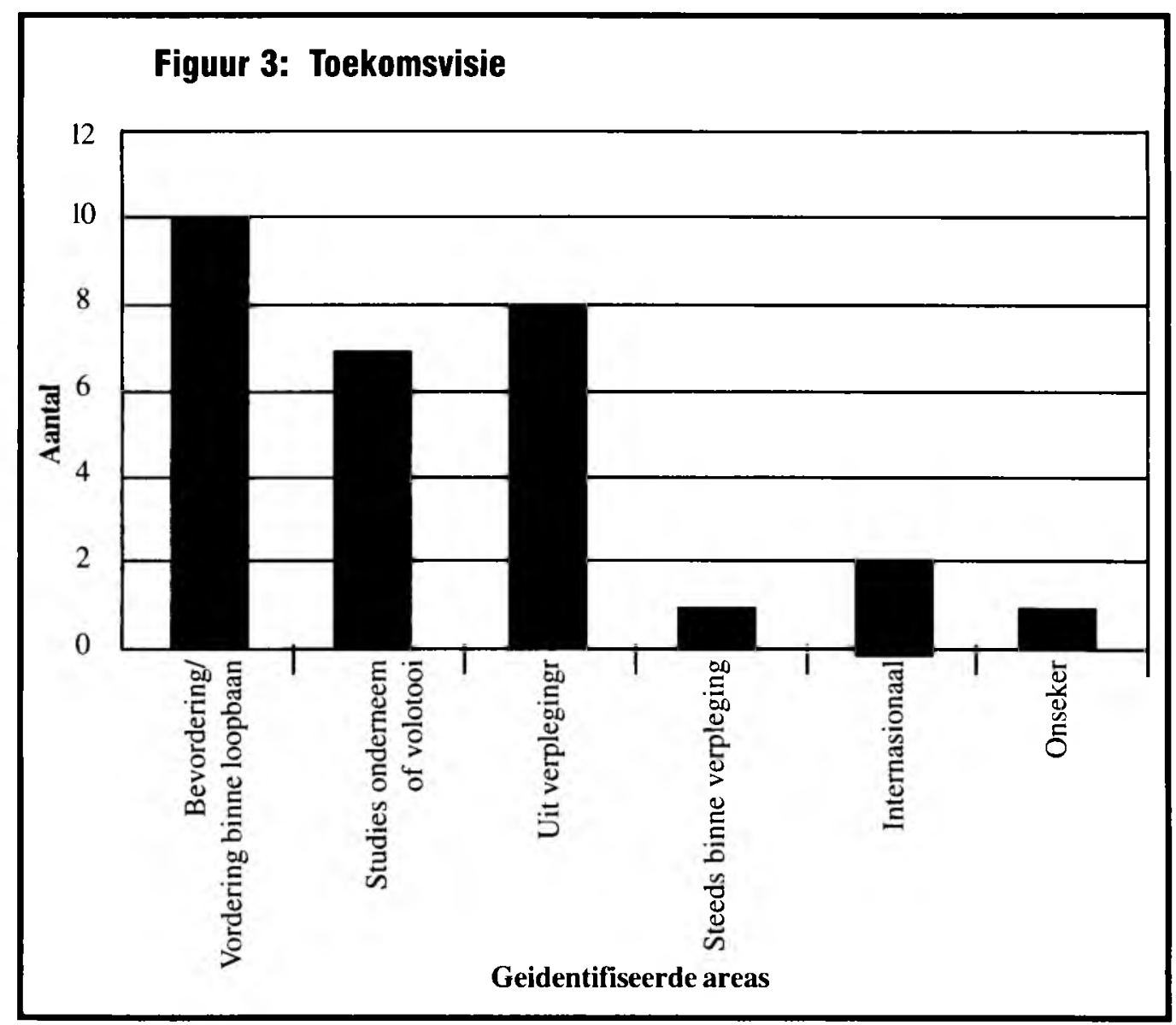

korttermyndoelwitte vir hom/haarself stel. Die individu moet dus 'n toekomsvisie hê wat haar/sy handelinge rig. Hierdie studie gee ' $n$ aanduiding van die hooftemas wat binne die individu se doelwitte oor 'n tydperk van 10 jaar geïdentifiseer is (Muller, 1998: 356).

Tien uit die nege-entwintig afgestudeerde studente van 1997 se doelwitte was gefokus op die bevordering of vordering binne haar/ sy loopbaan. Sewe uit die nege-en-twintig individue wou of studie onderneem of voltooi. Agt uit die nege-en-twintig afgestudeerde studente van 1997 wou uit verpleging gaan en van

- Peri-natale selfonderrig -3 individue

- Gevorderde ICU - 1 individu

- Gevorderde verloskunde - 1 individu

- Gevorderde ortopedie - 1 individu

Vier uit die negentien individue het ' $n$ graad onderneem of voltooi in B.Cur. Ed. et Admin. Drie van die negentien afgestudeerde studente van 1997 het die graad M.Cur. onderneem of voltooi, terwyl geen individue hul D.Cur.graad onderneem of voltooi het nie. Uit die negentien individue is daar egter een wat 'n kombinasieberoep volg, 'n student wat die basiese graad van B.Cur voltooi het en tans ' $n$ graad in die mediese rigting onderneem (Muller, 1998: 357).

Die "ander" binne die grafiek verwys na kursusse wat deur die afgestudeerde B.Cur.-studente van 1997 gevolg is of voltooi is, wat nie binne 'n spesifieke spesialiseringsveld gekategoriseer kan word nie. Die kursusse sluit onder meer die volgende in:

- Traumakursus (gestudeer op internasionale vlak)

- KPR (Kardiopulmonale resitasie) - instrukteurskursus

- Internasionale erkende babamasseringskursus

- MIV-kursus

- $\quad$ Verskeie kursusse wat deur die individu se werk self voorgeskryf is

- Kursus binne koste-ingeneurswese

- Besigheidsbestuurskursus

Soos reeds genoem, is dit volgens Muller (1998:358) belangrik dat elke individu langtermyn- en loopbaan verander. Een van die individue het genoem dat sy haarself oor die volgende 10 jaar steeds binne verpleging sien. Twee afgestudeerde studente het egter genoem dat hul oorsee (internasionaal) wil gaan. Terwyl een student onseker was oor hoe sy haarself sien oor die volgende tien jaar (Muller, 1998:356).

Figuur 15 gee ' $n$ duidelike weergawe van hoeveel afgestudeerde studente van 1997 van mening was dat hulle die regte loopbaankeuse gemaak het en dié wat gevoel het dat hulle die verkeerde loopbaankeuse gemaak het.

Negentien $(65.50 \%)$ van die nege-en-twintig studente het genoem dat hulle voel dat hulle die regte loopbaankeuse gemaak het, terwyl sewe (24.10\%) uit die afgestudeerde B.Cur.-studente gemeen het dat hul nie die regte keuse gemaak het. nie. Van die sewe wat van mening was dat hul die verkeerde loopbaankeuse gemaak het, is drie individue steeds binne verpleging, terwyl vier tans nie meer binne die verpleegprofessie praktiseer nie. Die balans van $10.4 \%$ verwys na drie individue met wie daar nie direk telefonies kontak gemaak is nie, maar van wie inligting verkry is van ' $n$ naasbestaande of vriendin wat vrae van die aard dus nie kon beantwoord nie (Muller, 1998: 357).

\section{Samevattende gevolgtrekking}

Die stappe van loopbaanbestuur behoort meer aandag in die verpleegkundige se werksomgewing te geniet. 
- $\quad$ Elke individuele verpleegkundige behoort bewus te raak van haar verantwoordelikheid om haar eie loopbaan te ontleed ten einde realistiese loopbaandoelwitte te formuleer.

- In ' $n$ dinamiese gesondheidsisteem behoort verpleegkundiges bewus te wees van nuwe beroepsmoontlikhede en -studiegeleenthede wat tot die bereiking van hul doelwitte in professionele ontwikkeling kan bydra.

- Verpleegkundiges moet eienaarskap neem van die besluite wat hulle in die bestuur van hulle loopbane neem.

- Verskeie inligtingstelsels is vir werwing van verpleegkundiges beskikbaar. Entrepeneurskap moet egter nie uit die oog verloor word nie.

- $\quad$ Professionele voortgesette leer is ' $n$ lewenslange proses wat tot suksesvolle loopbaanbestuur kan bydra.

\section{Beperkings en aanbevelings}

Die studie het egter beperkings deurdat die bevindings slegs van toepassing is op ' $\mathrm{n}$ bepaalde jaargroep, dié van 1997, en sodoende kan die bevindings nie veralgemeen word na ander jaargroepe nie (Brink, 1996: 200).

Met inagneming van bogenoemde word daar dus aanbeveel dat die studie toegepas word op verdere jaargroepe. Dit sal, soos reeds genoem aan die verpleegonderwys-instelling kennis verskaf aangaande die profiel van die afgestudeerdes, ten einde die program volgens die behoeftes van die leerders aan te pas.

\section{Bronnelys}

BRINK, HI 1996: Fundamentals of Research Methodology for Health Care Professionals. Soth Africa:Juta \& Company, Ltd.

DENOSA 2001: Recruitment. Nursing update, 25(2). Pretoria:Penta Publications (Pty) Ltd.

KIMMEL, LH 1998: Just got your pin? These tips can help you hit the ground running in your career. (in nursing). Nursing, May 1998. [Web:] http:// www.findarticles.com/cf $0 / \mathrm{m} 3231 / \mathrm{n} 5$ v28/20650820/ print.intml [05 Augustus 2001].

MILLER, JV 1986: The family-career connection. Overview. Eric Digest, 52. [Web:] http://www.ed.gov/ databases/ERIC_digests/ [05 Augustus 2001]

MULLER, M 1998: Nursing Dynamics. Second edition Sandton:Heineman.

NOLTE, AGW 1998: A textbook for midwives. First edition Pretoria:J.L. van Schaik Publishers.
NORTHEASTERNUNIVERSITY DIVISIONOF COOPERATIVE EDUCATION sa. 2001: Students-CareerServices Five Step Model. [Web:] http://www.coop.neu.edu/student/fivestep.html [05 Augustus 2001]

RAU (Randse Afrikaanse Universiteit), FAKULTEIT OPVOEDKUNDE EN VERPLEEGKUNDE 2001: Voorgraads. Johannesburg

RAU (Randse Afrikaanse Universiteit), DEPARTEMENT VERPLEEGKUNDE 2001: Studiehandleiding Verpleegkunde 4: Verplegingsdinamika. Johannesburg.

REITMAN, A 2001: Basics of Career Self-management. [Web:] http://www.thingamajob.com/career/articles/reit.../ 010115_career_self_manage.htm [05 Augustus 2001]

WALTERS, I.E. 1997. Self-knowledge for career management: An educational psychological model. Johannesburg:RAU. (Thesis- D.Ed. (Psych.))

WATKINS, RM, HERRIN, M \& MCDONALD, LR 1998: The Juxtaposition of Career and Family: A Dilemma for Professional Women. Advancing Women, 1(2). [Web:] http://www.advancing women.com/awl/winter $98 /$ awlv2_watkins5 [05 Augustus 2001]

WEBSTER,M. 2001. Profile. [Web:] http://www.m-w.com/ cgi-bin/dictionary [27 Oktober 2001]

WILSON, HS \& KNIESL, CR 1996: Psychiatric Nursing. Fith edition. United States of America:Addison-Wesley Nursing 